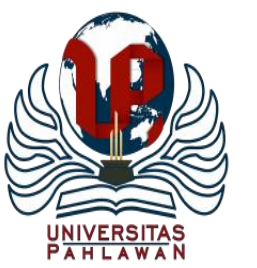

Jurnal Basicedu Volume 4 Nomor 3 Tahun 2020 Halm. 662 - 672

JURNAL BASICEDU

Research \& Learning in Elementary Education

https://jbasic.org/index.php/basicedu/index

\title{
Peningkatan Kemampuan Membaca Pemahaman Siswa Melalui Metode Pembelajaran Cooperative Integrated Reading And Compotion (CIRC)
}

\author{
Yulia Rahmi ${ }^{1}$, Ilham Marnola ${ }^{2}$ \\ Universitas Negeri Padang, Sumatera Barat, Indonesia ${ }^{1}$ \\ Universitas Negeri Malang, Jawa Timur, Indonesia ${ }^{2}$ \\ E-mail: Senzana93@yahoo.co.id ${ }^{1}, \underline{\text { ilhammarnola@stain.gpt.ac.id }}{ }^{2}$
}

\begin{abstract}
Abstrak
Tujuan penelitian ini adalah untuk mendeskripsikan peningkatan hasil kemampuan membaca pemahaman dengan menggunakan pembelajaran kooperatif tipe CIRC di kelas V SDN 04 Padang Ganting. Penelitian ini menggunakan pendekatan kualitatif dengan rancangan penelitian tindakan kelas. Rancangan penelitian ini meliputi (1) studi pendahuluan, penyusunan rencana tindakan, (2) kegiatan pelaksanaan penelitian yang terdiri dari tahap pelaksanaan tindakan, pengamatan dan tahap refleksi. Penelitian tindakan ini dilaksanakan dalam dua siklus. Peneliti bertindak sebagai penyaji/praktisi dalam proses pembelajaran, sedangkan pengamat adalah teman sejawat yang bertugas di tempat penelitian. Hasil penelitian menunjukkan bahwa penggunaan pendekatan kooperatif tipe CIRC dalam pembelajaran membaca pemahaman, efektif untuk meningkatkan kemampuan membaca pemahaman. Hal ini dapat dilihat dari nilai siswa yang diperoleh dari siklus I yaitu rata-rata nilai siswa 7,09, sedangkan pada siklus II nilai rata siswa yaitu 8,55. Dari hasil penelitian ini dapat diambil kesimpulan bahwa pembelajaran membaca pemahaman dengan menggunakan pendekatan kooperatif tipe CIRC dapat meningkatkan hasil belajar siswa.

Kata kunci: model pembelajaraan cooperative integrated reading and compotion (CIRC), membaca pemahaman
\end{abstract}

\begin{abstract}
The purpose of this study was to describe the improvement in reading comprehension results using CIRC type cooperative learning in class V SDN 04 Padang Ganting. This study uses a qualitative approach to the classroom action research design. The design of this research includes (1) preliminary studies, preparation of action plans, (2) research implementation activities consisting of the stages of implementing actions, observations and reflection stages. This action research was carried out in two cycles. The researcher acts as a presenter / practitioner in the learning process, while the observer is a colleague on duty at the research site. The results showed that the use of the CIRC type cooperative approach in learning to read comprehension was effective for improving reading comprehension skills. This can be seen from the value of students obtained from the first cycle which is an average student score of 7.09, while in the second cycle the average value of students is 8.55. From the results of this study it can be concluded that learning to read comprehension by using a CIRC type cooperative approach can improve student learning outcomes.

Keywords: Cooperative Integrated Reading and Composition (CIRC) Learning Model, reading comprehension
\end{abstract}

Copyright (c) 2020 Yulia Rahmi, Ilham Marnola

Corresponding author :

Address : Padang Ganting, Kab. Tanah Datar

Email : Senzana93@yahoo.co.id

Phone : 085272952434

ISSN 2580-3735 (Media Cetak)

ISSN 2580-1147 (Media Online)

DOI: $10.31004 /$ basicedu.v4i3.406 


\section{PENDAHULUAN}

Pembelajaran bahasa Indonesia mencakup empat aspek keterampilan yaitu mendengar, berbicara, membaca dan menulis. Keterampilan membaca mempunyai peranan yang penting baik dalam proses belajar mengajar di sekolah maupun dalam kehidupan sehari-hari. Dalam kurikulum bahasa dan sastra Indonesia dicantumkan tujuan pengajaran, salah satunya adalah agar siswa mengetahui apa yang dipelajarinya, sehingga ia mampu mengkomunikasikannya dengan baik lisan maupun tulisan, dan untuk hal itu perlulah seorang siswa untuk membaca. Melalui membaca seseorang akan tahu tentang sesuatu yang akan menambah pengetahuannya, sedangkan dalam lingkungan sekolah, dengan rajin membaca akan mudah dalam memahami suatu pelajaran.

International Association for Evaluation Education Achievement (IEA) (dalam (Harsanti \& Gemilang, 2017) mengungkapkan bahwa "kebisaaan membaca siswa Indonesia berada pada peringkat ke-26 dari 27 negara yang diteliti." Rendahnya minat dan kemampuan membaca antara lain tampak pada rendahnya kemampuan membaca mereka. Hal ini merupakan salah satu indikator bahwa pembelajaran membaca di sekolah belum maksimal.

Penggunaan pendekatan, metode, dan teknik membaca yang tidak tepat diasumsikan merupakan salah satu faktor penentu kurang maksimalnya pencapaiaan tujuan membaca di sekolah. Selain itu, alokasi waktu yang disediakan untuk pembelajaran masih sangat minim. Akibatnya pelatihan-pelatihan yang diberikan oleh guru untuk pelatihan membaca siswa cenderung diarahkan hanya membaca bacaan-bacaan pendek yang terdapat dalam buku paket. Pemahaman guru terhadap kiat-kiat pengembangan membaca yang baik juga disinyalir sangat kurang.

Pemahaman membaca di SDN 04 Padang Ganting sangat minim. Hal ini terbukti pada tes awal kelas V pada tahun ajaran 2010/2011, siswa mengalami kesulitan dalam memahami isi bacaan. Kesulitan tersebut pada dasarnya bermula dari kesulitan siswa dalam memahami isi bacaan, seperti: (1) siswa sulit menemukan gagasan utama. (2) siswa sulit dalam menjawab pertanyaa. siswa sulit membuat ringkasan wacana.

Untuk mengembangkan keterampilan membaca, pendidik harus melakukan inovasi dan kreativitas dalam menggunakan pendekatan pembelajaran sehingga kegiatan pembelajaran keterampilan membaca berlangsung maksimal, salah satu pendekatan yang biasa digunakan pendidik adalah pendekatan model pembelajaran Cooperative Integrated Reading and Compotion (CIRC). Pembelajaran Kooperatif adalah metode belajar, siswa bekerja berpasangan atau berkelompok dan bergantian secara lisan mengikhtisarkan, bagian-bagian dari materi yang dipelajari. Model Pembelajaran CIRC adalah model pembelajaran yang cukup sederhana, mudah, dan praktis untuk melatih kemampuan membaca pemahaman siswa.

Berdasarkan uraian di atas maka peneliti tertarik untuk melakukan suatu penelitian dengan judul "Peningkatan Kemampuan Membaca Pemahaman Siswa Kelas V Melalui Model Pembelajaran Cooperative Integrated Reading and Compotion (CIRC) di SDN 04 Padang Ganting.” 
Klein (dalam Farida, 2008) mengemukakan bahwa defenisi membaca mencakup: “(1) membaca merupakan suatu proses, (2) membaca adalah strategi, (3) membaca merupakan interaktif”. Dalam Kamus Besar Bahasa Indonesia (Departemen Pendidikan Nasional, 2005) dijelaskan bahwa membaca adalah "melihat serta memahami isi dari apa yang tertulis (dengan melisankan atau hanya dalam hati)." Sementara itu, Poerwodarminto (dalam Muschlisoh, 1995) mengatakan membaca yaitu melihat sambil melisankan suatu tulisan dengan tujuan ingin mengetahui isinya. Sedangkan, sebagai bentuk atau wujudnya, membaca dinyatakan sebagai suatu alat untuk mendapatkan gagasan-gagasan yang disusun serta dikembangkan sesuai dengan kebutuhan-kebutuhan sang pembaca.

Membaca adalah suatu proses melisankan lambang tertulis yang melibatkan mata dan otak. Pembaca sebagai komunikan dan penulis sebagai komunikator. Hubungan antara pembaca dan penulis tidak terjadi secara langsung. Pembaca tidak langsung berhadapan dengan penulis, tetapi berhadapan dengan pikiran-pikiran penulis yang diawali dengan tulisannya.

Pembelajaran membaca intensif merupakan kegiatan membaca yang bertujuan untuk menumbuhkan dan mengasah kemampuan secara kritis dengan menelaah, meneliti, serta memahami secara rinci suatu bacaan sehingga timbul pemahaman yang tinggi. Membaca pemahaman adalah salah satu jenis membaca yang harus dipelajari oleh siswa SD. Tingkatan membaca di sekolah dasar terbagi menjadi dua bagian yaitu membaca permulaan untuk kelas rendah, dan membaca lanjutan untuk kelas tinggi, membaca lanjutan inilah yang disebut membaca pemahaman.

Kata pemahaman dalam (Departemen Pendidikan dan Kebudayaan, 1990) berawal dari kata paham yang memiliki arti: “(1) pengertian, (2) pendapat pikiran, (3) mengerti benar akan sesuatu". Jadi memahami bacaan dapat dikatakan sebagai suatu sikap mengerti benar dengan bahan yang dibaca. (Harefa, Sukma, \& Desyandri, 2019) menambahkan bahwa "membaca pemahaman juga dapat menghubungkan antara apa yang mereka ketahui dengan apa yang mereka akan pelajari."

Membaca pemahaman berarti membaca untuk memahami isi bacaan yang merupakan representasi dari pikiran, ide, gagasan dan pendapat penulis. Penulis berhadapan dengan lambang-lambang bahasa, lambang itu terwujud dalam bentuk huruf, kata, kalimat, dan paragraf, dibalik lambang tersebut terdapat makna dan maksud. Pada saat lambang itu dipahami oleh pembaca, pembaca akan mengambil makna yang ada di baliknya. Akan tetapi, pada saat pembaca tidak memahami lambang yang dibacanya, maka makna yang ada di balik lambang itu tidak akan dapat dipahaminya.

Pembelajaran kooperatif adalah model pembelajaran yang di dalamnya mengkondisikan para siswa bekerja bersama-sama di dalam kelompok-kelompok kecil untuk membantu satu sama lain dalam belajar. Pembelajaran kooperatif didasarkan pada gagasan atau pemikiran bahwa siswa bekerja bersama-sama dalam belajar, dan bertanggung jawab terhadap aktivitas belajar kelompok mereka seperti terhadap diri mereka sendiri. 
(Sharan, 2009) menerangkan bahwa: "pembelajaran kooperatif menuntut siswa bekerja bersama-sama untuk mempelajari dan bertanggung jawab atas pelajaran mereka sendiri dan juga pembelajaran orang lain". Sedangkan menurut (Suprijono, 2009) menjelaskan bahwa "pembelajaran kooperatif adalah konsep yang lebih luas meliputi semua jenis kerja kelompok."

Menurut Slavin (dalam Farida, 2005) "tujuan utama CIRC khususnya dalam menggunakan tim kooperatif ialah membantu siswa belajar membaca pemahaman yang luas untuk kelas-kelas tinggi SD." Dalam artian bahwa pembelajaran tipe CIRC cocok dilaksanakan di kelas IV,V dan VI SD. Berdasarkan pendapatpendapat di atas dapat diambil suatu kesimpulan bahwa tujuan pembelajaran kooperatif adalah meningkatkan hasil belajar akademik, menumbuhan sikap sosial yang menerima keberagaman, serta meningkatkan kemampuan membaca pemahaman siswa seluas-luasnya.

\section{Coperative Integrated Reding and} Composition (CIRC) termasuk salah satu model pembelajaran cooperative learning yang pada mulanya merupakan pengajaran kooperatif terpadu membaca dan menulis yaitu sebuah program komprehensif atau luas dan lengkap untuk pengajaran membaca dan menulis untuk kelaskelas tinggi sekolah dasar. Namun, CIRC telah berkembang bukan hanya dipakai pada pelajaran bahasa tetapi juga pelajaran eksak seperti pelajaran matematika.

(Ariawan, Utami, \& Rahman, 2018) mengungkapkan bahwa Model CIRC merupakan model yang membantu siswa dalam pengembangan keterampilan membaca dan menulis siswa secara komprehensif. Sedangkan, (Oktafiani, Irdamurni, \& Damri, 2018) menyebutkan bahwa model pembelajaran CIRC adalah model pembelajaran yang menekankan kerja sama tim dalam menguasai kemampuan memahami bacaan. Ditambahkan oleh (Nurhidayah, Mulyasari, \& Robandi, 2017) bahwa CIRC dapat diartikan sebagai suatu model pembelajaran kooperatif yang mengintegrasikan suatu bacaan secara menyeluruh, kemudian mengomposisikannya menjadi bagian-bagian yang penting. Maka dapat dikatakan bahwa tipe CIRC adalah tipe pembelajaran kooperatif yang beranggotakan empat orang siswa yang terlibat dalam sebuah rangkaian kegiatan bersama, termasuk saling membacakan satu dengan yang lainnya, membuat prediksi tentang bagaimana cerita naratif yang akan muncul, saling membuatkan iktisar satu dengan yang lainnya, menulis tanggapan terhadap cerita, berlatih pengejaan serta perbendaharaan kata.

Dalam model pembelajaran CIRC, siswa ditempatkan dalam kelompok-kelompok kecil yang heterogen, yang terdiri atas 4 atau 5 siswa. Dalam kelompok ini tidak dibedakan atas jenis kelamin, suku/bangsa, atau tingkat kecerdasan siswa. Jadi, dalam kelompok ini sebaiknya ada siswa yang pandai, sedang atau lemah, dan masing-masing siswa merasa cocok satu sama lain. Dengan pembelajaran kooperatif, diharapkan para siswa dapat meningkatkan cara berfikir kritis, kreatif dan menumbuhkan rasa sosial yang tinggi (Putri, Koeswati, \& Radia, 2019). Metode CIRC adalah suatu metode pembelajaran yang dapat 
menggabungkan kegiatan menulis dan membaca yang diharapkan dapat meningkatkan kerjasama, berpendapat dan memberi tanggapan siswa.

(Suyitno, 2005) menjelaskan kegiatan pokok dalam CIRC untuk membaca meliputi rangkaian kegiatan bersama yang spesifik, yaitu (1) salah satu anggota atau beberapa kelompok membaca, (2) membuat prediksi atau menafsirkan isi bacaan, termasuk menuliskan apa yang diketahui, apa yang ditanyakan dan memisalkan yang ditanyakan dengan suatu variabel, (3) saling membuat ikhtisar/rencana penyelesaian masalah yang ada dalam bahan bacaan, (4) menuliskan penyelesaian masalah secara urut, dan (5) saling merevisi dan mengedit pekerjaan atau penyelesaian.

(Sharan, 2009) menjelaskan "langkah membaca dengan menggunakan CIRC adalah: membentuk kelompok membaca, siswa membaca bersama secara bergantian, menuliskan struktur cerita dan menuliskan sesuatu yang berkaitan dengan cerita, mencari makna kosa kata baru, menceritakan kembali, pengecekkan rekan dan tes."

Slavin (dalam Suyitno, 2005) menyebutkan kelebihan model pembelajaran CIRC sebagai berikut: (1) CIRC amat tepat untuk meningkatkan keterampilan siswa dalam menyelesaikan soal pemecahan masalah, (2) dominasi guru dalam pembelajaran berkurang, (3) siswa termotivasi pada hasil secara teliti, karena bekerja dalam kelompok, (4) para siswa dapat memahami makna soal dan saling mengecek pekerjaannya, (5) membantu siswa yang lemah, (6) meningkatkan hasil belajar khususnya dalam menyelesaikan soal yang berbentuk pemecahan masalah. Pembelajaran kooperatif tipe CIRC memiliki kekuatan untuk meningkatkan kemampuan membaca siswa karena peran guru tidak begitu dominan sehingga kesempatan siswa untuk lebih aktif dalam mengembangkan potensinya makin besar.

(Muslimin, 2001) menyatakan bahwa "hasil belajar akademik yang dimaksudkan dalam pembelajaran kooperatif meliputi pemahaman konsep-konsep yang sulit serta peningkatan kinerja ilmiah dalam tugas-tugas akademik." Kerjasama dan kolaborasi ditumbuhkan sehingga dapat terhindar dari rasa permusuhan ataupun pertikaian kecil yang menyebabkan kekerasan. Situasi belajar semacam ini memberi dampak nyata kepada siswa ketika berada dalam masayarakat. Penilaian adalah serangkaian kegiatan dan penggunaan beragam alat untuk memperoleh informasi tentang sejauh mana hasil belajar siswa yang dilakukan secara sistematis dan berdasarkan kriteria-kriteria tertentu.

Menurut (Slavin, 2005) dalam kegiatan membaca pemahaman dengan pendekatan tipe CIRC ada 5 langkah yang dapat dilakukan yaitu: “(1) penyajian kelas, (2) kegiatan kelompok, (3) persentasi kelompok, (4) penghargaan kelompok, dan (5) refleksi."

Tahap prabaca guru menyiapkan pembelajaran dan memotivasi siswa dengan menjelaskan tentang manfaat dari membaca, kemudian menjelaskan tujuan membaca pemahaman, membangkitkan skemata, membentuk kelompok siswa dan membagikan LKS. Setelah membagikan LKS guru mengarahkan siswa untuk mengikuti langkah-langkah kegiatan yang ada pada LKS. 


\section{METODE}

Subjek penelitian ini adalah siswa kelas $\mathrm{V}$ SDN 04 Padang Ganting yang berjumlah 20 orang, terdiri dari 12 orang perempuan dan 8 orang lakilaki. Penelitian ini dilaksanakan dalam beberapa siklus tindakan, tiap siklus dilaksanakan satu kali pertemuan. Penelitian ini merupakan penelitian tindakan kelas menggunakan pendekatan kualitatif dan kuatitatif. Adapun tahapan atau langkah yang dilakukan adalah (1) tahap perencanaan, (2)tahap pelaksanaan, (3) tahap pengamatan, (4) tahap refleksi. data dari penelitian di kelas ini berupa hasil tes, pengamatan, wawancara dan catatan lapangan dari pembelajaran tentang menemukan ide pokok paragraf dan kesimpulan dalam suatu wacana.

\section{HASIL DAN PEMBAHASAN}

\section{Siklus I}

Perencanaan pembelajaran siklus I disajikan dalam waktu satu kali pertemuan. Materi pembelajaran berupa teks wacana diambil dari surat kabar Padang Ekspress. Wacana tersebut berjudul " 800 Rumah Warga Kota Padang Terkena Banjir."

Pelaksanaan tindakan pada kegiatan awal, diawali dengan mengucapkan salam, meminta siswa untuk berdo'a yang dipimpin oleh ketua kelas selanjutnya memeriksa kehadiran siswa. Pelaksanaan kegiatan inti terdiri dari kegiatan prabaca, saatbaca dan pascabaca. Pada tahapan prabaca peneliti memberikan penjelasan tentang tugas mengamati gambar yang telah dipajang di depan kelas dan kemudian tanya jawab tentang gambar tersebut. Selanjutnya guru membagi siswa ke dalam 5 kelompok, setiap kelompok terdiri atas 4 orang. Tahap saatbaca dimulai dengan meminta siswa membaca dalam hati teks yang telah dibagikan, menarik gagasan utama dari sebuah paragraf dan meringkas teks bacaan, selanjutnya siswa diminta untuk saling berdiskusi dengan teman kelompoknya. Pada tahap pascabaca, masing-masing kelompok mempresentasikan hasil kerja dan kelompok yang lain menanggapi apakah yang disampaikan benar atau salah.

Kegiatan akhir peneliti memberikan evaluasi/kuis kepada setiap siswa berupa menjawab pertanyaan, menemukan gagasan utama dan meringkas bacaan yang telah dibaca. Evaluasi/kuis ini bertujuan untuk mengukur pemahaman siswa terhadap bacaan yang telah dibaca untuk mengetahui hasil pembelajaran siswa setelah pembelajaran dilakukan.

Fokus kegiatan guru dalam kegiatan pembelajaran adalah: (1) menyiapkan kondisi kelas, (2) memotivasi siswa dengan menjelaskan manfaat, (3) menjelaskan tujuan membaca pemahaman, (4) membangkitkan skemata siswa, (5) membentuk kelompok siswa, (6) membagikan Lembaran Kerja Siswa, (7) membimbing siswa dalam melakukan diskusi, (8) membacakan hasil diskusi kelompok ke depan kelas, (9) menyimpulkan pelajaran bersama siswa, (10) evaluasi, (11) penghargaan kelompok. Berdasarkan pengamatan, keberhasilan tindakan peneliti pada siklus I adalah $77.3 \%$ berada dalam keberhasilan baik, dari 11 karakteristik ternyata baru 6 karakteristik yang berkualifikasi sangat baik. Hal ini diperoleh dari pengamatan dengan menggunakan lembar observasi dari aspek guru. 
Fokus kegiatan siswa dalam kegiatan pembelajaran adalah: (1) menyiapkan kondisi kelas, (2) menyimak manfaat membaca, (3) menyimak tujuan membaca, (4) pembangkitan skemata, (5) membentuk kelompok belajar, (6) mendengarkan penjelasan guru tentang langkah kerja yang ada pada LKS, (7) melakukan proses pembelajaran, (8) membacakan hasil diskusi kelompok ke depan kelas, (9) melakukan tanya jawab tentang hasil diskusi, (10) menyimpulkan pembelajaran, (11) evaluasi. Berdasarkan pengamatan Keberhasilan tindakan siswa pada siklus I adalah 77.3 atau baik, dari 11 karakteristik ternyata baru 4 karakteristik yang berkualifikasi sangat baik.

Kegiatan refleksi dilakukan secara kolaboratif antara peneliti dan observer setiap pembelajaran berakhir. Dari hasil analisa penelitian dan diskusi dengan observer pada siklus

1, maka diperoleh hal-hal sebagai berikut:

a. Secara umum pelaksanaan pembelajaran telah berjalan sesuai dengan rencana pelaksanaan pembelajaran yang telah disusun.

b. Belum semua siswa yang aktif, untuk itu perlu ditingkatkan pembelajarannya.

c. Siswa banyak meribut dan tidak focus dalam mengikuti kegiatan pembelajaran, banyak siswa yang berbicara-bicara dengan teman saat lain membacakan hasil kerja kelompoknya di depan kelas.

d. Pelaksanaan pembelajaran belum optimal, karena rata-rata nilai akhir siswa masih rendah yaitu 70.9. Dimana skor terendah adalah 5.25 dan skor tertinggi adalah 8.65
Didapat kesimpulan bahwa hasil belajar siswa belum sesuai dengan yang diharapkan, untuk itu perlu dilanjutkan pada siklus II.

\section{Siklus II}

Perencanaan pembelajaran siklus II pada garis besarnya sama dengan perencanaan pembelajaran siklus I. Perbedaannya terdapat pada bahan bacaan yang digunakan sebagai materi pembelajaran. Pelaksanaan kegiatan inti terdiri dari kegiatan prabaca, saatbaca dan pascabaca sesuai dengan langkah-langkah pembelajaran membaca pemahaman dengan menggunakan pendekatan kooperatif tipe CIRC. Pelaksanaan kegiatan tahap prabaca siklus II, diawali dengan kegiatan membuka pelajaran, dengan menggunakan waktu yang efisien dalam pembelajaran, peneliti menyampaikan tujuan pembelajaran dan tugas-tugas belajar yang harus dikerjakan siswa dalam waktu yang terbatas. Selanjutnya peneliti melakukan pembangkitan skemata dengan memperagakan gambar "komputer". Fokusnya adalah untuk membangkitkan skemata siswa dan untuk menginterpretasi gambar yang diamati.

Pelaksanaan kegiatan tahap saatbaca siklus II dimulai oleh peneliti dengan meminta siswa membaca dalam hati teks yang telah dibagikan, mendiskusikan jawaban dengan teman satu kelompoknya dan menjelaskan kepada anggota kelompoknya yang belum begitu mengerti.

Pelaksanaan kegiatan tahap pascabaca siklus II yaitu masing-masing kelompok melaporkan hasil diskusinya ke depan kelas, kelompok yang lain menanggapi. Kegiatan akhir diberikan 
evaluasi/kuis kepada siswa. Evaluasi berupa menjawab pertanyaan, menemukan gagasan utama dan meringkas bacaan yang telah dibaca.

Pengamatan dilaksanakan untuk mendapatkan informasi bagaimana respon siswa dan peneliti dalam melaksanakan pembelajaran siklus II. Keberhasilan tindakan peneliti pada siklus II adalah 90,9 atau sangat baik, sebagian besar deskriptor telah terlaksana dengan baik pada siklus II ini. Keberhasilan tindakan peneliti pada siklus II adalah 88,6 atau sangat baik, sebagian besar deskriptor telah terlaksana dengan baik pada siklus II ini. Perbandingan keberhasilan belajar siswa siklus I dan siklus II dapat dilihat pada tabel berikut.

Tabel 1. Perbandingan Keberhasilan Hasil Belajar Siswa

\begin{tabular}{|l|l|}
\hline \multicolumn{1}{|c|}{ Siklus I } & \multicolumn{1}{c|}{ Siklus II } \\
\hline Rata-rata nilai proses: & Rata-rata nilai \\
7 & proses: 9,05 \\
\hline $\begin{array}{l}\text { Rata-rata nilai } \\
\text { evaluasi: } 7,18\end{array}$ & $\begin{array}{l}\text { Rata-rata nilai } \\
\text { evaluasi: } 8,06\end{array}$ \\
\hline
\end{tabular}

Berdasarkan tabel di atas terungkap bahwa keberhasilan membaca pemahaman mengalami peningkatan. Siklus I dalam proses diskusi ratarata nilai siswa 7 pada siklus II meningkat menjadi 9,05. kemudian untuk rata-rata nilai evaluasi juga meningkat dari 7,18 pada siklusi I menjadi 8,06 pada siklus II.

Pembahasan difokuskan pada aktivitas guru dan siswa dalam pembelajaran peningkatan kemampuan membaca pemahaman dengan menggunakan pendekatan kooperatif tipe CIRC bagi siswa kelas V SDN 04 Padang Ganting.
Sebelum melaksanakan pembelajaran di kelas, peneliti membuat rancangan pembelajaran. Dalam menyusun rancangan pembelajaran tersebut ada beberapa komponen yang menjadi dasar penyusunannya, komponen itu mencakup (1) standar kompetensi, (2) kompetensi dasar, (3) indikator, (4) tujuan pembelajaran, (5) materi pembelajaran, (6) pendekatan dan metode, (7) kegiatan pembelajaran, (8) sumber/alat pembelajaran, (9) penilaian. Semua butir tersebut terdapat dalam rencana pembelajaran pada siklus I dan siklus II, tetapi antara siklus I dan siklus II juga ada perbedaannya yaitu didasarkan pada hasil refleksi pelaksanaan tindakan dan dilengkapi pada pertemuan berikutnya.

Hasil penelitian pada siklus I, kegiatan kurang berjalan dengan baik, sebab peneliti kurang membangkitkan skemata siswa dengan mengamati gambar. Kemudian juga intonasi peneliti pada saat menjelaskan manfaat juga tidak begitu jelas. Pada siklus I gambar tentang banjir ditampilkan dengan jelas dan rinci. Dengan mengamati gambar secara bebas, pengetahuan dan pengalaman siswa yang berkaitan dengan isi bacaan yang akan dibacanya menjadi aktif dan siap digunakan untuk memaknai isi bacaan.

Sebagaimana tahap prabaca, tahap saatbaca juga terungkap dalam penelitian. Aktivitas penting yang dilakukan pada tahap saatbaca adalah (1) membaca dalam hati bacaan yang diperoleh, (2) siswa berdiskusi dengan teman sekelompoknya agar semua anggota kelompok memahaminya, (3) guru mengawasi kegiatan siswa.

Untuk penggalian informasi pada tahap saatbaca dilakukan dengan belajar kelompok.

\section{Pembahasan siklus I}


Kegiatan belajar kelompok kurang dapat dilakukan sesuai dengan semestinya, karena dalam pembagian kelompok siswa berebut mencari tempat duduknya masing-masing sehingga waktu lebih banyak habis untuk membagi kelompok. Kegiatan mengisi LKS dapat berjalan dengan baik siswa bisa bekerja sama dengan baik dan siswa saling membantu dalam kelompoknya.

Kegiatan pada tahap pascabaca juga belum semuanya terlaksana, melaporkan hasil diskusi ke depan kelas terlaksana dengan baik, tanggapan dari kelompok yang belum tampil belum terlaksana karena siswa masih malu-malu mengeluarkan pendapatnya. Pemberian evaluasi terlaksana dengan baik, tanggapan dari kelompok yang belum tampil belum terlaksana karena siswa masih malumalu mengeluarkan pendapatnya. Pemberian evaluasi terlaksana dengan baik. Hasil tes membaca pemahaman siswa menggambarkan prestasti belajar siswa. Keberhasilan evaluasi dapat diketahui dari rata-rata nilai evaluasi siswa siklus I, yaitu 7,18. Berdasarkan hasil pengamatan siklus I yang diperoleh maka dilanjutkan ke siklus II.

\section{Pembahasan siklus II}

Pembelajaran membaca pemahaman dengan menggunakan pendekatan kooperatif tipe CIRC pada siklus II sudah berjalan dengan baik. Peneliti sudah menyampaikan tujuan dan tugas-tugas belajar secara rinci, akibatnya siswa aktif merespon pembelajaran sehingga proses pembelajaran terlaksana sesuai dengan yang diharapkan.

Pembangkitan skemata sudah dilakukan peneliti dalam pembelajaran membaca pada siklus
II telah memenuhi standar yang dituntut. Pada waktu pembangkitan skemata, siswa diberi kebebasan untuk mengamati gambar yang berkaitan dengan bacaan yang sudah disiapkan peneliti tujuannya agar pengetahuan dan pengalaman siswa yang berkaitan dengan isi bacaan yang akan dibacanya menjadi aktif dan siap digunakan untuk memakna isi bacaan.

Sebagaimana tahap prabaca, tahap saatbaca juga terungkap dalam penelitian. Aktivitas penting yang dilakukan pada tahap saatbaca adalah (1) membaca dalam hati bacaan yang diperoleh, (2) siswa berdiskusi dengan teman sekelompoknya agar semua anggota kelompok memahaminya, (3) guru mengawasi kegiatan siswa.

Kegiatan belajar kelompok berjalan dengan baik, dan dapat dilakukan sesuai dengan semestinya, karena dalam pembagian tempat duduk siswa sudah diatur menurut kelompok. Kegiatan mengisi LKS dapat berjalan dengan baik siswa bisa bekerja sama dengan baik, dan siswa saling membantu dalam kelompoknya

Tahap pascabaca juga terungkap dalam pembelajaran, kegiatan yang dilakukan dalam tahap ini adalah (1) menyajikan hasil diskusi ke depan kelas, (2) kelompok yang belum tampil menanggapi, (3) meluruskan jawaban siswa yang dilakukan oleh guru sehingga siswa mengetahui jawaban yang benarnya supaya siswa lebih paham, (4) memberikan evaluasi individual, memberikan penghargaan kepada kelompok dengan nilai tertinggi.

Kegiatan pada tahap pascabaca juga terlaksana dengan baik, melaporkan hasil diskusi ke depan kelas terlaksana dengan baik, tanggapan 
dari kelompok yang belum tampil sudah terlaksana karena siswa sudah berani mengeluarkan pendapatnya. Pemberian evaluasi terlaksana dengan baik dan pemberian penghargaan kepada kelompok dengan nilai tertinggi juga bisa dilaksanakan dengan baik. Hasil tes membaca pemahaman siswa menggambarkan prestasi belajar siswa. Dari analisis penelitian pada siklus II nilai rata-rata kelas adalah 8,55. Berdasarkan hasil pengamatan siklus II yang diperoleh maka pelaksanaan siklus II sudah sangat baik dan guru sudah berhasil dalam usaha peningkatan kemampuan membaca pemahaman dengan pendekatan kooperatif tipe CIRC.

\section{SIMPULAN}

Penggunaan pendekatan kooperatif tipe CIRC dalam pembelajaran membaca pemahaman terbukti efektif dapat meningkatkan hasil belajar karena pembelajaran dilaksanakan sesuai dengan perancangan, pelaksanaan dan evaluasi. Setelah dilakukan penelitian maka terjadi peningkatan kemampuan siswa memahami isi bacaan, dapat dilihat dari perolehan nilai rata-rata membaca siswa pada siklus I, yaitu 71,8 dan pada siklus II terjadi peningkatan menjadi 8,55. Jadi pembelajaran membaca pemahaman dengan menggunakan pendekatan kooperatif tipe CIRC dapat meningkatkan kemampuan siswa memahami isi bacaan.

\section{DAFTAR PUSTAKA}

Ariawan, V. A. N., Utami, N. T., \& Rahman. (2018). Peningkatan Keterampilan Membaca Pemahaman Siswa Sekolah Dasar Melalui Implementasi Model CIRC Berbantuan Media Cetak. Al-Aulad: Journal of Islamic
Primary Education, 1(2), 95-104 https://doi.org/10.15575/al-aulad.v1i2.3529

Departemen Pendidikan dan Kebudayaan. 1990. Kamus Besar Bahasa Indonesia. Jakarta: Balai Pustaka

Departemen Pendidikan Nasional. (2005). Kamus Besar Bahasa Indonesia edisi ketiga. Jakarta: Balai Pustaka

Farida, R. (2008). Pengajaran Membaca di Sekolah Dasar. Jakarta: Bumi Aksara.

Harefa, F. T., Sukma, E., \& Desyandri. (2019). Jurnal basicedu. JURNAL BASICEDU Research \& Learning in Elementary Education, 3(2), 435-442.

Harsanti, \& Gemilang, A. (2017). Pendidikan Karakter Melalui Pembelajaran Sastra. Jember: Universitas Press.

Muschlisoh. (1995). Materi Pokok Pendidikan Bahasa Indonesia 3. Jakarta: Universitas Terbuka.

Muslimin, I. (2001). Model Pembelajaran Kooperatif. Surabaya.

Nurhidayah, I., Mulyasari, E., \& Robandi, B. (2017). Penerapan Model Pembelajaran Kooperatif Tipe Circ untuk Meningkatkan Kemampuan Membaca Pemahaman. Jurnal Pendidikan Matematika, 3(1), 43-54.

Oktafiani, W., Irdamurni, \& Damri. (2018). Efektivitas Model Pembelajaran Cooperative Integrated Reading And Composition (CIRC) Untuk Meningkatkan Kemampuan Membaca Pemahaman Anak Disleksia. UNES Journal of Education Scienties, 2(1).

Putri, Y. I. S., Koeswati, H. D., \& Radia, E. H. (2019). COOPERATIVE INTEGRATED READING AND COMPOSITION ( CIRC ) TERHADAP. JURNAL BASICEDU Research \& Learning in Elementary Education, 3(2), 442-449.

Sharan, S. (2009). Handbook of Cooperative Learning (Inovasi Pengajaran \& Pembelajaran untuk Memacu Keberhasilan Siswa di Kelas). Yogyakarta: Imperium. 
672 Peningkatan Kemampuan Membaca Pemahaman Siswa Melalui Metode Pembelajaran Cooperative Integrated Reading And Compotion (CIRC) - Yulia Rahmi, Ilham Marnola

DOI: 10.31004/basicedu.v4i3.406

Slavin, R. . (2005). Cooperative Learning (Teori,

Riset dan Praktik). Bandung: Nuansa Media.

Suprijono, A. (2009). Cooperative Learning: Teori dan Aplikasi PAIKEM. Yogyakarta: PustakaBelajar.

Suyitno, A. (2005). Mengadopsi Pembelajaran CIRC dalam Meningkatkan Keterampilan Siswa Menyelesaikan Soal Cerita. 